\title{
AZ EMBER-ROBOT BIZTONSÁGA A STRUKTURÁLATLAN KÖRNYEZETBEN
}

\section{HUMAN-ROBOT SAFETY IN AN UNSTRUCTURED ENVIRONMENT}

\author{
Fődi Gábor
}

Óbudai Egyetem Bánki Donát Gépész és Biztonságtechnikai Mérnöki Kar, Magyarország, Budapest, Népszínház utca 8.,fodi.gabor@gmail.com

\begin{abstract}
There are still several questions yet to be solved regarding to human robot safety in an unstructured environment. Therefore it is important to inspect those aspects that have effect on it. If we manage to overcome those issues, the wide spread of mobile robots in unstructured environments can rapidly grow. The dynamically changing environment present numerous challenges that are unlike of those that have already been implemented in industrial environment.
\end{abstract}

Keywords: safety engineering, human-robot, unstructured.

\section{Összefoglalás}

A mobil robotok biztonságával és megbízhatóságával kapcsolatban még komoly problémák merülhetnek fel, ezért fontos megvizsgálni azokat a tényezőket, amelyek a fennálló problémaként megjelennek. Ha sikeresen áthidaljuk őket, akkor felgyorsulhat a mobil robotok elterjedése a strukturálatlan környezetben. A dinamikusan változó környezet számos olyan kihívást hordoz magában, amelyek miatt nem lehet az ipari környezetben már sikeresen alkalmazott biztonsági eljárásokat változtatások nélkül hasznosítani.

Kulcsszavak: biztonságtechnika, ember-robot, strukturálatlan.

\section{Bevezetés}

Ahhoz, hogy egy robot a strukturálatlan környezetben dolgozni tudjon, fel kell készíteni azokra a váratlan eseményekre és hatásokra, amelyekkel ott találkozik. Egy feladat végrehajtása számos kihívást jelent, ennek érdekében olyan képességekkel kell ellátni a gépeket, amelyekkel a felmerülő helyzeteket kezelni tudják. Emellett továbbra is az ember-robot kapcsolatban a kulcs a biztonság. Ezért olyan ember érzékelési rendszert kell létrehozni, amely autonóm módon, szenzorokkal érzékeli a környezet változását [1]. Ezeket az információkat ké- pes felismerni és azokhoz alkalmazkodni. A strukturált ipari környezetben használt megoldásokat nem lehet egy az egyben átvenni egy dinamikusan változó környezetbe. A gép nem támaszkodhat előre beállított környezeti feltételekre, ehelyett folyamatosan információra van szükség a megfelelö döntéshozatalhoz. A biztonság kérdése egy kisméretü és -tömegü robot esetében kevésbé tünhet fontosnak, de szükség, hogy a tevékenységét szabályozzuk és megfelelö keretek közé szorítsuk. Ahhoz, hogy a strukturálatlan környezetben is hasonló biztonsági szintet érjünk el, mint, az ipari robotoknál, az együttmüködés 
szintjének még sokat kell fejlődnie. A cikkben azok az eszközök és módszerek kerülnek vizsgálatra, amelyekkel a robotok megfelelően tudnak kommunikálni a környezettel és onnan információt szerezni, így megfelelő biztonsággal használhatóak emberek környezetében is. Ahhoz, hogy a biztonságot megfelelö alapra helyezzük, meg kell vizsgálni a két fél kapcsolatát [5]. A kommunikáció nehézségét az adja, hogy a minket körül vevő világ sztochasztikus, folyton és dinamikusan változik. Vannak olyan robotkörnyezetek, amelyek szekvenciális és multiágens jellegüek is lehetnek, illetve csak részlegesen figyelhetőek meg.

\section{Robot mozgások}

A strukturálatlan környezetben elsősorban mobil robotok dolgoznak. Egy feladat elvégzéséhez szükséges, hogy a robot eljusson a kijelölt célhoz, ehhez a leggyakrabban használt megoldások a szárazföldi egységek esetében a kötött vagy szabad pályán mozgó lánctalpas vagy normál kerekes megoldások vagy a járórobotok a jellemzőek. Ehhez mozgása során érzékelnie kell a környezetet, amely lehetővé teszi számára, hogy nagy hatékonysággal navigáljon a környezetben. A mozgások során egy fontos veszélyforrás a bizonytalanság, amely abból ered, hogy a környezet csak részleges figyelhető meg és a robotnak sztochasztikus a mozgása [2]. Azonban ha egy közelítéses módszert használunk, szintén fel kell készülni a hiba lehetőségre, mert a robotnak ilyenkor nincs pontos információja környezetéről a sztochasztikus vonások tökéletes modellezésével sem. Ezek helyett érdemesebb determinisztikus döntéshozatalt használni a mozgások esetében, amellyel a legvalószínübb állapotot tudja a gép kiválasztani a feltérképezett környezetből. A Markov döntési folyamattal jól lehet modellezni, milyen döntést kell hozni a robotnak bizonytalanság esetén. Ez a módszer akkor alkalmazható, ha az állapota teljesen megfi- gyelhető és egy állapotátmenet esetében kell számolni a bizonytalansággal. A módszer segítségével kaphatunk egy optimális eljárást, amely egy kérdéses esetben megmondja a robotnak, mit tegyen egy adott helyzetben. Így kezelni tudjuk a mozgás során keletkező hibákat, amelyekkel növelhető a biztonság szintje. Azonban ha a környezet csak részleges megfigyelhető, a döntési modellt is módosítani kell, a részlegesen megfigyelhető Markov döntési modellt alkalmazzuk. Ebben az esetben a robotnak van belső kép állapotáról vagy rendelkezik elegendő információval a döntés meghozataláról, strukturált, így könnyen frissíthető valamint a belső állapotváltozók megfeleltethetőek egy valós fizikai állapotnak a környező világból. A belső állapotában ilyenkor definiálunk egy stratégiát, így nem csak a rendelkezésre álló információk alapján tud dönteni, hanem az alapján is, amit nem ismer. Ilyenkor információ gyüjtést végez. Ezzel azonban olyan mértékü információ halmazt hozhatunk létre, amely meghaladja a mai eszközök feldolgozó kapacitását, ezért a legjobb, amit tehetünk, hogy a bizonytalanságot a minimumra csökkentjük. A minimalizálásra jó módszer a tárgy menti navigálás heuresztikus módszere, ebben az esetben a robot ismert referenciapontok mentén vagy azok közelében halad.

\section{3. Érzékelők és aktuátorok [3] [4]}

Az önállóság fokozása érdekében a mobil robotok esetében fontos az információ szerzést biztosító szenzoroknak, amelyek érzékeli a környezet változásait, valamint a robot mozgásban szerepet játszó aktuátoroknak. A biztonságot befolyásoló tényező, hogy a szenzorok érzékelési pontossága még messze elmarad az ember érzékszerveinek fejlettségétől.

$\mathrm{Az}$ alkalmazott érzékelők két csoportba oszthatjuk: lehetnek passzívak, mint a kamerák, amelyekkel a robot képes megfigyelni környezetet és leképezni a környeze- 
tet. Aktív érzékelőről akkor beszélünk, ha az a környezetből sugárzott vagy visszavert energiákat érzékeli. képérzékelők, amelyek fénysugarakat olyan digitális információvá alakítják át egy AD konverterrel, amiből végül a pixelekböl álló képet kapjuk meg, Ehhez CMOS és CCD szenzorok váltak elterjedté a gyártók körében. A sztereolátás szerepe megnőtt a robottechnikában, az ember ennek köszönhetően tud pontosan mozogni, felismeri a távolságokat és megfogni bizonyos dolgokat. A robot számára mélységi információt is közvetít, amely segítségével le tudja képezni a világot három dimenzióban.

Az aktuátor egy szerkezeti egység, amelyet általában a robotkar csuklójában helyezünk el, egy meghajtó vagy beavatkozó egység, amit leginkább az ember izomrendszerhez lehet hasonlítani. Müködési mód szerint osztályozva három eltérő hajtású lehet:

- hidraulikus;

- pneumatikus;

- villamos.

.A villamos hajtás alkalmazásának esetében előny, hogy könnyen irányítható és gazdaságos, de nagyüzemi terhelésnél inkább a hidraulikus mód a jellemző. Ezek önérzékelők, amelyek a robot számára adnak tájékoztatást saját állapotáról. Ez alapján megállapíthatjuk, milyen pozícióban állnak a robot egyes csuklói. Erre a feladatra jól használható a forgójeladó, amely egy elektromechanikus eszköz, ami megmutatja a fordulatszámot, az elfordulás szögét vagy a pozíciót. Müködhet mechanikai-, optikai-, vagy mágneses érzékelés elvén is.

A kutatások arra irányulnak, hogy egy olyan robotokat hozzanak létre, amelyek képesek arra, hogy az embert érzékeljék a környezetükben és ezáltal egy ember érzékelési rendszert hozzanak létre a biztonságos működéshez. Az érzékelők információi alapján le kell képezni a környezetből kapott jeleket és ezeket átadni a mozgást vég- ző egységekhez, illetve a karokhoz. Mivel az érzékelés összetett folyamat, a tapasztalataink szerint a nehézséget az adja, hogy minden környezetben jelen lévő zavaró jeleket hogyan zárjuk ki, hogy a leképezés a lehető leginkább hasonlítson a valós körülményekhez. Ameddig ez nem valósul meg, a robot viselkedését nem lehet teljes biztonsággal előre megjósolni. A vizsgálataink során azt állapítottuk meg, hogy a tökéletes leképezéshez három feltételnek kell teljesülnie:

- minél több információt kell szereznünk a környezetböl, amely elégséges ahhoz, hogy a megfelelő döntést meghozzuk;

- törekedni kell az információk strukturáltságra, megfelelő elrendezésére, hogy az könnyen frissíthető legyen;

- a belső állapotváltozók megfeleltethetők egy-egy valós fizikai világbeli állapotváltozónak.

A gépek számítási kapacitás egyre nagyobb lesz, de még nem intelligensek, a cél, hogy a közeljövőben olyan szenzorokkal és érzékelőkkel lássák el a gépeket, hogy akár érintéssel, szaglással vagy éppen tapintással is információhoz jussanak. Végül a nem csak az elöre programozott algoritmusok alapján tudjanak reagálni az őket ért hatásokra, hanem meg is értsék azokat.

\section{Következtetések}

A cikk keretében megvizsgáltam, hogy egy mobil robot esetében hogyan tudjuk a biztonságot növelni, hogy megbízhatóan tudjanak dolgozni emberek környeztében. Annak érdekében, hogy a leképezés a gépet körülvevő környezethez a feltérképezéshez szükséges feltételeket vizsgáltam meg, amelyek kiindulási alapot adni egy későbbi felügyeleti rendszer kiépítéséhez.

\section{Köszönetnyilvánítás}

Ezúton szeretnék köszönetet mondani az Óbudai Egyetem Robottechnikai Szakkollégium részére, amelynek tagjaként számos 
szakmai és anyagi támogatást kaptam jelen szakmai tudományos publikációm elvégzéséhez. A szakkollégium kiemelt segítséget nyújt az Óbudai Egyetem tehetséges hallgatóinak és doktoranduszainak.

\section{Szakirodalmi hivatkozások}

[1] Robotalkalmazások. Szerk.: BME MOGI. Budapest, BME Mechatronika, Optika és Gépészeti Informatika Tanszék, 2014. 319 oldal

[2] Robotmechanizmusok. Szerk.: BME MOGI. Budapest, BME Mechatronika, Optika és
Gépészeti Informatika Tanszék, 2014. 163 oldal

[3] Fődi G., Pausits P.: Az ember és a robotok közötti kapcsolatok vizsgálata Bólyai Szemle XXIV. évfolyam 2. szám Budapest 2015. 3644. $p$.

[4] Kömlödi F.: Autonóm mobil robotok. Égenföldön informatika.. TYPOTEX Budapest 2008 588-613. p.

[5] Pausits P., Szögi G., M. Nallbani, Rudas I. J., Haidegger T.: Identification of Risks in the Application of Surgical Robotics, 19. IEEE INES Konferencia, Pozsony, 2015, 147-151. 